\title{
Law Enforcement for Tax Reporters That Are Not Based On Actually Transactions through Electronic Taxes (E- Tax)
}

\author{
Eddy R \\ Department of Law, Kader Bangsa University \\ Jl. Ryacudu No.88, SU I, South Sumatera, Palembang, Indonesia \\ eddyr1256@gmail.com
}

\begin{abstract}
This research is focused on aspects of law enforcement, especially in the area of tax law. In addition, the study examines the process of tax law enforcement which tends to emphasize criminal law rather than administrative law. This research was conducted using normative juridical methods which are based on primary legal materials. The results showed that emphasizing the criminal aspect in enforcing tax law would only jeopardize the main purpose of tax administration in collecting tax revenue that is very much needed for public spending. The results of this study are The tax law in Indonesia is regulated in Article 23A of the 1945 Constitution which reads: "Taxes and other levies that are coercive for the purposes of the state are regulated by Law." So the tax law is a compulsory citizen obligation, where the arrangement is submitted to the state in accordance with applicable law.
\end{abstract}

Keywords:

Law Enforcement, Electronic Tax, Tax Reporters.

\section{Introduction}

Internet technology has a considerable influence on the development of world information. It used to require quite a long time to get information about the events that happened today. But now information can spread quickly. It only takes a second to get information from the internet. At present, information is the most important key in human life. (Agrawal, 2017). The influence of the development and application of information and communication technology also reaches other aspects of government, one of which is the taxation aspect. Tax institutions use this technology to provide convenience in providing services and information to their customers. Similar to the development of information technology, tax revenue is a source of state revenue which is increasingly important. Tax is one of the biggest sources of state revenue. (Mardismo, 2016). This tax revenue is very instrumental in the welfare of society in Indonesia. (Rahayu, 2013). Therefore, the results of tax collection in our country today are the main source of state revenue whose contribution is expected to increase every year. Along with this, various efforts have been made by all officials of the Directorate General of Taxes in increasing tax revenue from taxpayers by carrying out tax reforms from taxpayers by carrying out reforms in the taxation system.

This renewal in the taxation system is marked by the application of the latest information technology in taxation services. This improvement in taxation services can be seen with the development of modern tax administration and information technology in various aspects of activities. A fundamental change related to tax modernization occurred at the beginning of 2005, namely the implementation of new types of services to taxpayers in the context of submitting notification letters and the submission of an annual notification using electronic (efiling). Precisely on January 24, 2005 to coincide at the Presidential Office, the President of the Republic of Indonesia, together with the Directorate General of Taxes, launched an e-Filing product or Electronic Filing System, which is a tax reporting / submission system with an electronic Tax Return (e-Filing) which done through a realtime on-line system.

In the decision of the Director General of Tax Number KEP-88 / PJ. / 2004 dated May 14, 2004 concerning Submission of Electronic Notification Letters, it was stated that the submission of electronic Notification Letters (eSPT) was carried out through the designated Application Service Provider Company by the Director General of Taxes. For further regulation, the Regulation of the Director General of Tax Number KEP05 / PJ / 2005 was issued on January 12, 2005 concerning Procedures for Submitting Electronic Notification Letter (e-Filing) through Application Service Provider Company (ASP) (Suandi, 2014). 


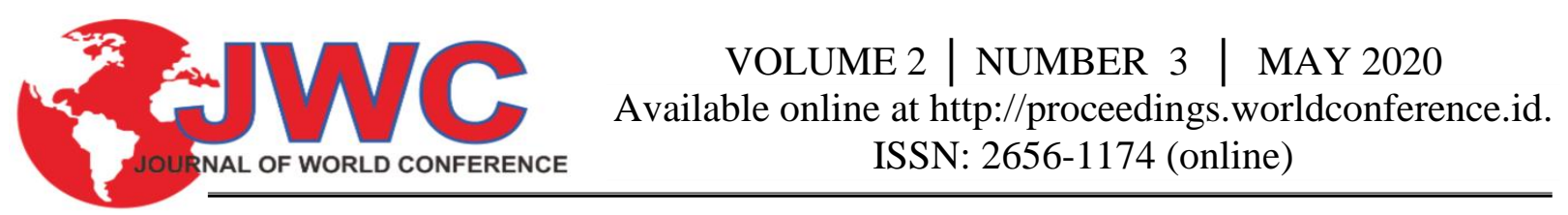

With this system, it is easier for taxpayers to fulfill their obligations without having to queue at tax offices so that they feel more effective and efficient. In addition, the sending of Notification Data (SPT) can be done anywhere and anytime both inside and outside the country, not dependent on office hours and can also be done on holidays and without the presence of a Tax Officer ( 24 hours in 7 days), where the data will be sent directly to the Directorate General of Taxes database with internet facilities distributed through one or several Application Service Provider Companies (ASP). The use of e-filing can reduce the burden of paper tax administration. (Sambodo, 2014).

With the ease of fulfilling taxation obligations, it is expected to increase taxpayer compliance. In addition, the transition in the way of submitting and reporting the Notification Letter (SPT) can facilitate and provide benefits for the Directorate General of Taxes (DGT) itself in managing taxes. Therefore, it is necessary to support all parties continuously so that the improvement of services to taxpayers continues to run and at the same time the creation of a modern tax administration. But at this time not all taxpayers use e-filing because taxpayers still consider that the use of computer systems in SPT reporting is very confusing and difficult. This is because there are still many taxpayers who do not understand about the operation of e-Filing and the ability of taxpayers to use e-Filing is still minimal. In addition, the socialization of e-Filing to taxpayers has not yet been maximized and is ongoing. Whereas computerized SPT reporting has greater benefits for taxpayers and the Directorate General of Taxes (DGT). In addition to the ability of taxpayers, differences in perceptions regarding usefulness, perceptions regarding ease of use and user satisfaction with e-Filing also determine whether this system is acceptable or not. (Mo, 2013).

The perception of usefulness determines whether a system is acceptable or not. Taxpayers who think that eFiling will be useful for them in reporting tax returns because they are interested in using it. The greater their interest in using it, the greater the intensity of users in using the information system. And vice versa what will happen if the taxpayer considers e-Filing is not beneficial for him in terms of reporting the SPT, then what will happen is the taxpayer becomes unwilling to use e-Filing. This results in a decrease in the intensity of the use of e-Filing by users. (Ayu, 2011).

Perceived ease of use also determines whether a system is acceptable or not. Taxpayers who think that eFiling is easy to use will encourage them to continue to use the system. The convenience provided by e-Filing will cause taxpayers to be happy in using it and will override the shortcomings that exist in e-Filing. Vice versa, if the taxpayer has felt the easiness of e-Filing, what will happen is that the taxpayer will not be afraid and not eager to use it. This perception will reduce the interest of taxpayers in using e-Filing (Wulandari, 2012).

Indonesia is currently carrying out a national development that is carried out continuously covering all fields of life, so the Indonesian people are always experiencing developments that are in line with the development and progress of the times. In connection with the implementation of national development, in the administration of state government, a source of income is used to finance the government of the state as outlined in the form of the State Expenditure Budget. Tax is one source of state revenue as a form of mandatory contribution to the state owed by individuals or entities that are coercive based on the Law, with no direct compensation and is used for state needs for the maximum prosperity of the people.

The task of the government in principle is to try and aim to create prosperity for its people, therefore the government must come forward and intervene, actively move in the field of community life, especially in the economy in order to achieve people's welfare, for the success of this effort, the state seeks its financing by collect tax. (Tait, 2018).

In order to improve services to taxpayers and to better provide legal certainty and anticipate developments in information technology and developments that occur in material provisions in the taxation field, besides that it is also intended to increase the professionalism of the tax apparatus, increase the transparency of tax administration, and improve compliance Voluntary Taxpayers are then issued Law Number 28 Year 2007 concerning the Third Amendment to Law Number 6 Year 1983 concerning General Provisions and Tax Procedures, based on the philosophy of the 1945 Constitution in which provisions stipulate that upholds citizens' rights and places tax obligations for taxpayers as a state obligation. The norm is contained in Article 23A of the 1945 Constitution, namely "Taxes and other levies that are coercive for the purposes of the country are regulated by law".

The issuance of Law No. 28/2007 concerning the Third Amendment to Law No. 6/1983 concerning General Provisions and Tax Procedures, the tax collection system in Indonesia underwent a very fundamental change, both in terms of characteristics and patterns, namely:

1. That tax collection is an embodiment and service as well as the role of the Taxpayer directly and jointly carry out the tax obligations required for state financing and national development;

2. The responsibility for implementing tax obligations, as a reflection of obligations in the field of taxation, rests with the taxpayers themselves. The government in this case the taxation apparatus in accordance with its function is obliged to conduct guidance, research and supervision of the implementation of taxpayers' tax obligations based on the provisions outlined in tax legislation; 


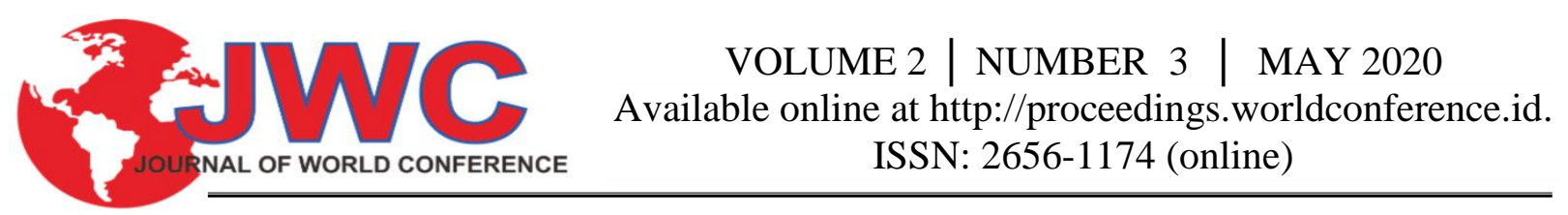

3. Members of the taxpayer community are given the trust to be able to carry out national cooperation through the system of calculating, calculating and paying their own tax payable (Self-Assessment), so that through this system the implementation of tax administration is expected to be carried out more neatly, in a controlled, simple and easy manner understood by community members (Salamun, 2013).

Cling the obligation for taxpayers to pay taxes to the state does not rule out the possibility of being burdened for some taxpayers, so that there is a desire to take actions intended to minimize the tax burden unlawfully. The development of taxation in the community has a very important role as one of the largest sources of state revenue, but on the other hand tax liabilities are also vulnerable to various criminal acts, one of which is the falsification of tax invoices.

The tax collection process is carried out by a government agency namely the Directorate General of Tax (DGT) which is structurally under the Ministry of Finance (Dwi Indriyani dan Pujianto, 2014). The Directorate General of Taxes has the duty and obligation to provide excellent service to taxpayers in carrying out their tax obligations to the maximum extent possible. Along with the increasing number of taxpayers, it is required an increase in service quality. In modern times the Directorate General of Taxes has developed tax services by modernizing taxation. DGT modernized the tax administration system to increase state revenue.

With the development of increasingly sophisticated information technology, in this case marked by the digital era, it makes opportunities and challenges for the Directorate General of Taxes (DGT). One change in the form of services to taxpayers provided by the Directorate General of Taxes (DGT) is the existence of services in the form of a tax payment system with an online system; monitoring system for reporting and payment of taxes (e-payment), NPWP registration (e-registration), SPT reporting and sending or submitting SPT (e-SPT) that can be done at post offices and demand deposits, as well as designated banks (Yuniaswati, 2016).

Compliance Taxpayers (tax compliance) can be identified from the compliance of taxpayers in registering themselves, compliance to remit returns (SPT), compliance in calculation, and payment of tax payable, and compliance in arrears payments. The issue of compliance becomes important because simultaneous non-compliance will lead to efforts to avoid taxes, such as tax avoidance, which results in reduced depositing of tax funds into the State treasury (Mahmud, 2018).

The problem that has occurred so far is the queue of SPT submission from taxpayers who are entering the reporting due date and the limited number of SPT data recording officers so that the recording process becomes slow even becomes the arrears of recording. In order to be able to assist services in reporting and recording SPT data quickly, accurately, and accurately, the Directorate General of Taxation has carried out tax modernization in one of its applications using electronic SPT (e-SPT).

Electronic SPT or e-SPT is an application (software) made by the Directorate General of Taxes for use by Taxpayers for ease in submitting SPT. The advantages of using e-SPT applications are that SPT submission can be done quickly and safely, because the attachments are in the form of CD / diskette media, tax data are well organized, the e-SPT application system organizes corporate tax data properly and systematically, calculations are carried out quickly and right because it uses a computer system, ease in making tax reports, data submitted by taxpayers is always complete, because the numbering of forms using a computer system and avoiding waste of paper.

In the Director General of Taxes Regulation Number: 6 / PJ / 2009, which contains the Procedures for Submitting Notification in Electronic Form, it is explained in Article 2 Paragraph 1 that "Taxpayers must submit SPT in electronic form (e-SPT)" By implementing the system online taxation is expected to increase taxpayer compliance for tax reporting and payment.

In the era of globalization a lot of tax fraud occurs in the regions and it is very detrimental to the State, online tax fraud can be linked to the Law on Information and Electronic Transactions so that criminal sanctions can be given (Mcgee, 2012). Based on the background, the problems to be examined are:

1. What is Law Enforcement for Tax Reporters Not Based on Actual Transactions through Electronic Tax (E-Tax)?

2. What is the Prevention and Eradication Strategy for Tax Reporting that is not based on Actual Transactions?

\section{Literatur Review}

\subsection{Theory of Taxation}

Tax is a public contribution to the state (which is imposed) owed by those who are obliged to pay it according to general regulations (the law) with no achievement returned which can be directly appointed and whose use is to finance public expenditures due to the state's task to administer government.

Understanding tax as an achievement to the government that is owed through general norms and which can be forced, without any counter-achievements that can be demonstrated in individual terms, is intended to finance government spending. Article 1 number 1 of Act Number 28 of 2007 concerning the Third Amendment to Act Number 6 of 1983 concerning General Provisions and Tax Procedures, as amended by Act Number 16 of 2009 


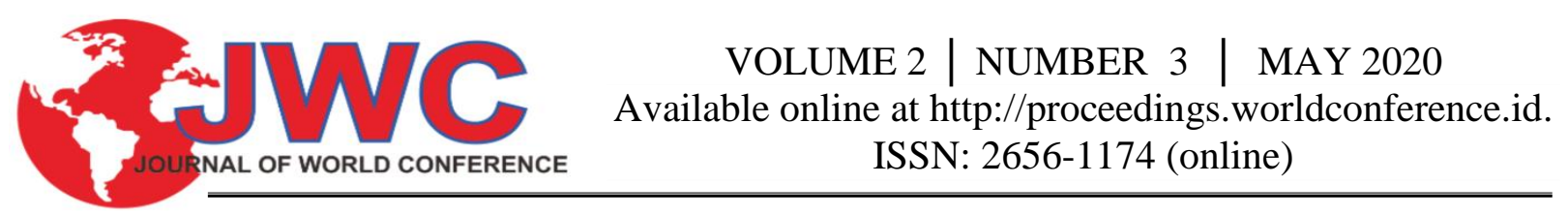

2012)The statute approach is carried out by examining all relevant legal regulations relating to the legal issues to be written, namely research on norms contained in the Criminal Procedure Code, the Criminal Law Code.

\section{Result and Discussion}

\subsection{Law Enforcement for Tax Reporters Not Based on Actual Transactions through Electronic Tax (E-Tax)}

According to Soejono Soekanto law enforcement does not merely mean the implementation of legislation. Even though it is deep the reality of Indonesia is the tendency. So the notion of law enforcement is so popular. There is even a tendency to interpret law enforcement as the implementation of court decisions. This narrow understanding clearly contains weaknesses, because the implementation of legislation or court decisions can occur precisely disturbing peace in the community's social relations. (Soekanto, 2015).

Law Enforcement is an effort to be translated and realizing the legal desires of crime becomes a challenge. According to Sajipto Raharjo, law enforcement is an attempt to bring the ideas of legal certainty, social benefits and justice into reality. The process of manifesting these three ideas is the essence of law enforcement (Sudarto, 2016).

The tax law in Indonesia is regulated in Article 23A of the 1945 Constitution which reads: "Taxes and other levies that are coercive for the purposes of the state are regulated by Law." So the tax law is a compulsory citizen obligation, where the arrangement is submitted to the state in accordance with applicable law. However, in practice, perversion in the effort to achieve the tax target should always be used by unscrupulous tax officials, taxpayers and tax consultants to cooperate and planned to commit crimes in the field of taxation such as embezzlement, avoidance, deviation, extortion and forgery of documents whose main purpose is to obtain the maximum profit or enrich themselves, so that in time it can cause distortion or state wealth distribution.

It is common knowledge that tax crimes are not infrequently committed by tax officers, or carried out jointly with persons associated with formal juridical taxation institutions, both as assistants, perpetrators and intellectual actors. As it is known that Taxes are coercive based on the Law so that if they are not adhered to or violated they will create sanctions for the perpetrators.

One form of fraud in taxation is tax evasion. Tax evasion is an attempt to smuggle taxes, a form of reducing tax owed by violating tax provisions, for example:

1. Not reporting some sales;

2. Enlarge costs in a fictitious way.

3. Collect tax but not offense.

Tax authorities in Indonesia in carrying out their duties have two major functions, namely the service function and the function of law enforcement. In addition to the service function, the Directorate General of taxation also conducts law enforcement for tax law violators which is divided into mild law enforcement and heavy law enforcement. Soft law enforcement is subject to administrative violations, while Hard Law Enforcement is imposed on taxation crime, sanctions imposed are special administrative sanctions and criminal sanctions.

Following is a summary of several articles in the General Taxation Provisions book (KUP) which is imposed on taxation crimes including, in (KUP):

1. Article 36A

2. Article 38 which reads Everyone who due to his negligence:

a. did not submit a Notification Letter; or

b. submit a Notification Letter, but the contents are incorrect or incomplete, or attach information that is not true so that it can cause a loss in state income and the act is an act after the first act as referred to in Article 13A,

3. Article 39 paragraph 1

4. Article 39

5. Article 41 Article 41- Article 43

As it is known that the crime of tax fraud, money laundering and corruption is a series of crimes that are interrelated to one another, but the handling is not always the same. (Sahetapy, 2014) For example for cases of tax fraud, the settlement may be outside the trial. The KUP Law provides an opportunity for tax evasion to be free from the bondage of criminal law. In Indonesia, the tax sector is the main source of state funding, both for development, defense and government administration purposes. Given the importance of the function and role of the tax for state administration, crime in taxation must be prevented and eradicated. One of the ways to eradicate and prevent tax crime is to implement an anti-money laundering regime. In line with that, every criminal in the field of taxation must be punished and the proceeds of the crime confiscated by the state in accordance with applicable laws and regulations. In Indonesia, the tax sector is the main source of state funding, both for development, defense and government administration purposes. Given the importance of the function and role of the tax for state 


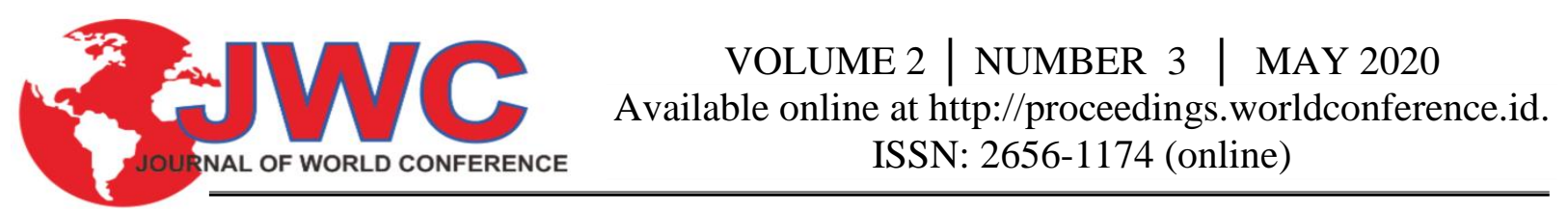

Dwi Indriyani dan Pujianto. 2014. Persepsi Wajib Pajak Orang Pribadi Atas Efektivifas Self Assesment System dan Sanksi Pajak dalam Keterkaitannya dengan tindakan Tax Evasion Pada Kantor Pelayanan Pajak Pratama Palopo. Makassar: Universitas Hasanuddin.

Mahmud, M. 2018. Criminal Policy, Pendekatan Integral Penal Polivy dan Non Penal Policy dalam Penanggulangan Kejahatan. Medan: Pustaka Bangsa Press.

Mardismo.2016. Perpajakan Edisi Revisi. Yogyakarta: Andi.

Mcgee, R. W. 2012. The Ethics of Tax Evasion: Perspevctive. London: Spinger.

Mo, P. L. 2013. Tac Avoidance and Ati Avoidance Measures in Major Developing Economies. USA: Greenwood Publishing Group.

Rahayu, S. K. 2013. Perpajakan Indonesia: Konsep \& Aspek Formal Cetakan Kedua. Yogyakarta: Graha Ilmu.

Sahetapy, J. 2014. Kejahatan Korporasi. Bandung: Eresco.

Salamun, A. 2013. Pajak Citra dan Pembaharuannya, Revisi dari Buku Pajak Citra dan Bebannya. Jakarta: PT Bina Rena Pariwara.

Sambodo, A. 2014. Pajak Dalam Entitas Bisnis. Jakarta: Salemba Empat.

Soekanto, S. 2015. Faktor- Faktor yang mempengaruhi Penegakan Hukum. Jakarta: Rajawali.

Suandi, E. 2014. Hukum Pajak Edisi 6. Jakarta: Salemba Empat.

Sudarto. 2016. Kapita Selekta Hukum Pidana. Bandung: Alumni.

Sugiyono. 2012. Metode Penelitian Kuantitatif dan R\&D. Bandung: Alfabeta.

Tait, A. A. 2018. Value Added Tax: International Practices and Problem. USA: International Monetary Fund.

Wulandari, E. 2012. Pengaruh Pemeriksaan Pajak Terhadap Tax Evasion dan Implikasinya Terhadap Penerimaan Pajak. Jakarta: Universitas Komputer Indonesia.

Yuniaswati, E. 2016. Pengaruh Sanksi Pajak Administrasi Pajak dan Pemer. Bandung: Universitas Pasundan.

Zain, M. 2018. Manajemen Perpajakan. Jakarta: Salemba Empat.

\section{Biography / Biographies}

Eddy $\mathbf{R}$ is a graduate student of Master of Law at Kader Bangsa University and also an tax consultant. He started school in 1965-1971 at Elementary School Perguruan Gotong Rajong in Plaju; in 1971-1974 at Junior High School Kristen in Palembang; in 1974-1977 at Senior High School YMIK Bersubsidi in DKI Jakarta. Then, Eddy continued studying in 1985-1986 at Dr. Soetomo University in Surabaya. After that, in 2014-2017 he continued to study in Bachelor of Law at Sjakhyakirti University in Palembang, and then in 2017-2019 he continued to study in Master of Pulic Administration at Sjakhyakirti University in Palembang. 